Farideh Haghshenas Kashani, Assistant Professor, Faculty of Management, Central Tehran Branch, Islamic Azad University (Tehran, Iran); Zakiyeh Shahmirzaloo, MA Degree, Faculty of Management, Central Tehran Branch, Islamic Azad University (Tehran, Iran)

\title{
DEVELOPING MARKETING STRATEGIES USING CUSTOMER RELATIONSHIP MANAGEMENT AND DATA MINING (CASE STUDY: PERPEROOK CHAIN RESTAURANTS)
}

Along with increasing competitiveness in the service industry to increase the number of customers and gain competitive advantage by creating customer satisfaction, using data mining concepts has attracted the attention of the researchers and the industries as a new tool for this purpose. In this regard, fast food industry, as an industry having an increasing growth during recent years, is considered as a very attractive market for the customers. The current study aims to utilize data mining algorithms to categorize the customers in fast food industry and propose marketing strategies tailored to each group of customers identified. The statistical population of this research includes the records submitted in the integrated system of Perperook chain restaurants, which is over 3000 records. Furthermore, the data mining algorithms, specifically decision tree and Quest algorithm, have been used in this study to categorize customers according to the orders submitted in the system. The results of this study indicate that the customers of Perperrok fast food can be categorized into three main groups: healthy, voluminous, and free-living customers. At the end of the research, detailed results and strategies associated with any of the main groups of customers are presented along with practical suggestions.

Keywords: customer relationship management, data mining, Apriori algorithm, decision tree.

DOI: 10.21272/mmi.2017.3-13

Introduction. The main purpose of Customer Relationship Management (CRM) is to develop a deeper understanding of customers to maximize the customers value in long-term. From literature's perspective, CRM framework can be divided into operational and analytical [1]. Operational CRM refers to automating business processes, while analytical CRM can help the organization to better recognize the profitable groups of customers and allocate the resources more effectively. Data mining technique is one of the famous tools of analyzing customers within analytical CRM framework. Many organizations collect and store valuable data about their current customers, potential customers, suppliers, and business partners. However, inability to discover the valuable information hidden in the data hinders organizations from moving from data to profitable and valuable knowledge. Data mining tools can help organizations to discover the knowledge hidden in the great mass of data. Application of data mining tools in CRM has emerging trends in the world economy. Analyzing and understanding the behaviors and features of the customers is the base of developing a competitive CRM strategy. In order to attract and retain potential customers and maximize customers' value, the appropriate data mining tools suitable for extracting and identifying useful knowledge and information from the great mass of customers' data are considered as a supportive tool to make important CRM decisions (Holm et al., 2011). Using customers profile is of great importance in most business activities since the first step in marketing strategies is market segmentation and developing profiles associated with the segmented market results. In fact, the value of market segmentation lies in the correct and accurate customer profile. Analyzing customer value is one of the methods used to identify customer's behavioral features [2]. Customer's loyalty can be evaluated based in this analysis. Customer's loyalty doesn't only refer to customer's long-term retention, but also refers to developing a sustainable relationship with the customer to encourage them to purchase more in the future [3]. Exploring the data associated with the customers, the information records will be organized, the process of identifying important customers will automatically go on, the method of identifying special and valuable customers from the whole list of 
Ф.Х. Кашані, 3. Шахмірзалу. Розробка стратегій маркетингу з використанням управління взаємовідносинами 3 клієнтами та збору даних (приклад дослідження: сеть ресторанов Perperook)

customers will change, and the loyal customers will be finally identified. Generally, there is no doubt that correct form of customer relation is one of the most important factors of development, especially in service organizations [4]. Some examples of these organizations include banks and chain fast foods, in which Customer Relationship Management has a key role. The customers in these organizations are, in fact, the most important source of profitability. Therefore, identifying them and analyzing the data associated to them is very important for the company's profit. In this regard, this study aims to develop suitable and practical marketing strategies by analyzing Perperook chain fast food customers' cart and identifying their rules and principals using data mining algorithms.

Theory. Customer Relationship Management. Customer Relationship Management is a set of processes and system enablers supporting business strategies to develop long-term profitable relations with special customers [4]. Customer Relationship Management is a philosophy for attracting and retaining customer, increasing customer value, sustainability, and implementing customer-oriented strategies. Customer Relationship Management improves the relationships with the customer by focusing on a holistic picture of how to integrate customer vale, needs and expectations, and behavior through analyzing the data obtained by customer interaction [2]. Customer Relationship Management refers to methods the organization used to gain customer's loyalty during their life and, therefore, to increase competitive advantage and profitability. In other words, the potential advantages of CRM are: (1) increased customer's loyalty and customer retention, (2) increased profitability, (3) creating value for the customer, (4) customizing products and services, (5) increased quality of products and services and creating fewer processed. The main core of Customer Relationship Management activities is understanding profitability and retaining profitable customers [5]. According to Ghazanfari and Alizadeh and Teimourpour [6], customer relationship management can be divided into operational and analytical categories. Operational CRM refers to automating business strategies, while analytical CRM refers to analyzing customers' features and behaviors in order to support CRM strategies. Thereupon, analytical CRM helps superior differentiation and better allocation of the resources to most profitable groups of customers. Data mining tools are the best means of analyzing customer data in analytical CRM since they can help the organization discover the knowledge hidden in the great mass of data. In Customer Relationship Management, grouping is important as it creates a profile for different customers and provides the possibility of strategic planning on customer groups.

Data mining and applications. The term data mining was first introduced by Dr. Gregory PiatetskyShapiro in 1989 in a conference on artificial intelligence in Detroit. Knowledge discovery and data mining is an interdisciplinary and growing field incorporating many fields such as database, statistics, machine learning, and other related areas to extract the valuable information and knowledge hidden in a great mass of data [6]. Several definitions have been proposed regarding data mining concepts. For example, according to Han and Kamber [7], data mining means exploring and analyzing a great mass of data to discover meaningful patterns and rules. Data mining process is sometimes called knowledge discovery. The concept of knowledge discovery or data mining refers to a set of methods involving all areas of work, from data gathering to implementing the algorithm and model evaluation [8]. According to PangNing and Steinbach and Kumar [9], data mining technique is developed to cleanup large databases, and to discover new and useful patterns that might remain unknown in these databases. Generally, data mining techniques refer to extracting hidden information and the relations prevailing among them from the great mass of data [10]. Among the newly developed techniques, data mining is the process of discovering meaningful knowledge, such as patterns, continuities, important structures, and deviations, from large databases [11]. Data mining is a fundamental tool necessary for revealing demographic characteristics of the customers [6]. Data mining techniques can be used to achieve a wide range of objectives. Some of its applications include:

- $\quad$ Identifying profitable customers and their profile 
- Predicting the customer's buying behavior

- Focusing marketing activities on potential customers with higher probability of buying

- Estimating advertisement efficiency

- Optimizing the share of customer's shopping cart

- Side and overhead selling to customers based on previous purchases

- Predicting scams and fraud

One of the most useful areas of data mining is Customer Relationship Management. Data mining has entered all areas of Customer Relationship Management, namely customer retention [4]. Customer retention is considered the core component of CRM cycle and is of great importance. Customer satisfaction, which refers to the current situation and his/her expectations, is necessary and essential for customer retention [12]. According to the studies carried out by American researchers, new customer acquisition costs is 5 times greater than the cost of retaining an existing customer. This is specifically achieved through service department [2].

Market segmentation. The concept of market segmentation was first introduced by Wendell $\mathrm{R}$. Smith, and American expert, in the middle 1950, which is, in fact, a technology to categorize customers into groups having similar features and tendency towards similar patterns [13]. In particular, market segmentation categorizes customers into groups of similar characters in terms of demography, geography, behavioural characteristics, and marketing strategies. Confronting markets with specified and segmented demands guides marketing strategies towards increased profit expected from the market. Most of market studies are focused on estimating how variables such as demography and social and economic situations can be used to predict consumption differences and loyalty to a specific brand [2]. This method is especially useful for organizations using sales promotion programs and targeted services for different groups of customers. In order to categorize customers, one feature of the customer, namely customer profitability, calculated by the organization is considered as decision-making feature, and other features of the customer are considered as conditional features. Therefore, the purpose of categorizing data is to reduce the great number of conditional features based on the value of decisionmaking features [14]. The main core of marketing strategy is market segmentation. Marketing strategy includes two parts: selecting the target market and developing an efficient marketing plan to be successful in the target market. Therefore, market segmentation is a trend to identify and separate buyers' features to:

- Select the markets that the organization wants to, or can, deliver its products and services.

- Design products and marketing plans to meet the requirements of the buyers.

According to this principle in marketing that the customers having similar features will also have similar behavior against the organization and its products, and given the point that customers with similar features are positioned in similar groups and market segments in the market segmentation methods, it can be expected that the loyalty status of the customers positioned in a given market segment of an organization is almost similar. The Table 1 shows distribution of some articles in the field of market segmentation.

Literature review. In their study entitled "Estimating customer lifetime value based on RFM analysis of customer purchase behavior", Khajvand et al.[15] focused in customer's loyalty and profitability to increase market share. Customer lifetime was used in their study to categorize the customers of a cosmetic company. To do so, two approaches were taken. The first approach used RFM methodology to categorize the customers, while an additional parameter, called the frequency of observing product items, was added to RFM method in the second approach. Comparing the two approaches indicated that adding this parameter makes no difference in categorizing the customers. Therefore, customer lifetime is allocated to each segment based on weighted RFM method. The result of customer lifetime for different segments can be used to explain marketing and marketing strategies. In their paper entitled "Analyzing customers' shopping cart using 
Ф.Х. Кашані, 3. Шахмірзалу. Розробка стратегій маркетингу з використанням управління взаємовідносинами 3 клієнтами та збору даних (приклад дослідження: сеть ресторанов Perperook)

association rules in Shahrvan chain stores", Shahrabi and Soofi-Neyestani [16] localized the customers based on their different conditions (e.g., geographic and economic conditions), market, shopping culture, etc., using association rules and clustering algorithms. In their study, the best algorithm tailored to different conditions was determined by comparing, evaluating, and implementing the algorithms mentioned above in one of the Iranian chain stores, using customers' shopping cart analysis, stores' arrangement, and all issues related to customer decision, according to the competitive market, social culture, and customers buying patterns in Iran. However, customer decision depends on their income level and different stores available in different regions, i.e., the number of stores and their variation in a given region. According to the researches performed from 2000 to 2011, 14,972 articles published were about data mining techniques (DMT), 216 of which, published in 159 journals, were about data mining applications. According to the studies carried out, the growth trend in data mining techniques was mainly expertise-oriented, while the growth trend in the articles related to data mining applications was mainly focused on solving the problem occurred on the organization [17]. Nan-Chen Hsieh [18] performed a study entitled "An integrated data mining and behavioral scoring model for analyzing bank customers". Ngai et al.[4] addressed reviewing and categorizing the literature in the context of data mining applications in Customer Relationship Management. In his study, the author reviewed selected articles from 2000 to 2006. The term data mining was first introduced by Dr. Gregory Piatetsky-Shapiro in 1989 in a conference on artificial intelligence in Detroit. Since then, several articles have written in this context. Kim et al.[19] used neural networks to manage loans. In an article entitled "Customer relationship management in the hairdressing industry: An application of data mining techniques", Wei et al.[20] addressed clustering the customers in hairdressing industry. They clustered the customers using k-means algorithm and self-organizing map (SOM), and used RFM model to examine research variables. Their results indicated four major groups of customers: loyal, potential, new, and lost customers. Finally, the marketing strategies for each group were determined. In an article entitled "An efficient CRM-data mining framework for the prediction of customer behaviour", Bahari and Elayidom [21] proposed a model to retain customers using data mining techniques. To do so, they used Bayesian neural network and simple neural network. They collected the data related to bank customers in Portugal from 2008 to 2010 for analysis, and prepared them to feed into WEKA software. The result of their study indicated that simple neural network model is more accurate.

Research methodology.

The present study is an applied research regarding its purpose since its results can be an effective guideline for other researches and industries. In order to collect research data, the real customers' data submitted in Perperook chain restaurants were used. The statistical population of the research included all customers of Perperool chain fast food. Given using the real data of customers' transactions in this research, the samples available for analyzing customers' data were used. According to the reports of this company's branches, the number of samples in this study is considered to be near 3000 records. Moreover, since this study led to discovering pattern and describing the profile of customers in an industry, and since the purpose of data mining studies is knowledge discovery and using the knowledge discovered in the future, this research is considered as a descriptive-development research.

Research procedure. In order to determine the factors influencing customer purchase and identify customer profile in this study, first, the references and documents available in PubMed, Google Scholar, and SID databases were investigated. Using these databases, the factors to be considered were identified in the form of variables such as demographic characteristics and customers' shopping cart. These factors were written in the form of a table of variables for further investigation, and the details associated with any of them, namely data type and range, were specified. Finally, a checklist was pre pared based on these variables to collect the required data. Then, the data collected through checklist were fed to the SPSS 22 software. The data set of this research included 3000 records of Perperook fast food customers in the second half of 2015. Preprocessing, including correcting or deleting null data, determining the permissible limit and correcting impermissible values, conducting new calculations for some features and converting 
them to other features were performed on the data to improve them for using in analysis tool. Data mining methods and SPSS Clementine 14 software, and classification algorithms including decision tree and association rules in particular, were used to analyze the data obtained.

Table 1 - Research variables

\begin{tabular}{|c|c|c|c|}
\hline No. & Feature & Description & Type \\
\hline 1 & ID & Customer account number & Numerical \\
\hline 2 & AGE & Age & Numerical \\
\hline 3 & SEX & Sex & Binary \\
\hline 4 & VALUE & The monetary volume purchased & Numerical \\
\hline 5 & PMETHOD & Payment method & Nominal \\
\hline 6 & CUSTOMERS PRODUCTS PURCHASED & Shopping cart products & Binary \\
\hline
\end{tabular}

\section{Algorithms used.}

Decision tree. One of the well-known algorithms in classification method is decision tree algorithm. The structure of a decision tress is a tree structure, like flowchart, so that each internal node in this structure specifies a test on a feature, and each branch of the tree shows the output of this test. Leaf nodes also represent classes. The highest node in the tree is the root. Figure 1 shows a decision tree. This figure illustrates the concept of the possibility of buying a computer by a customer, which predicts whether the customer is interested in buying the computer or not. The internal nodes and leaf nodes are shown by rectangle and ellipse, respectively [7].

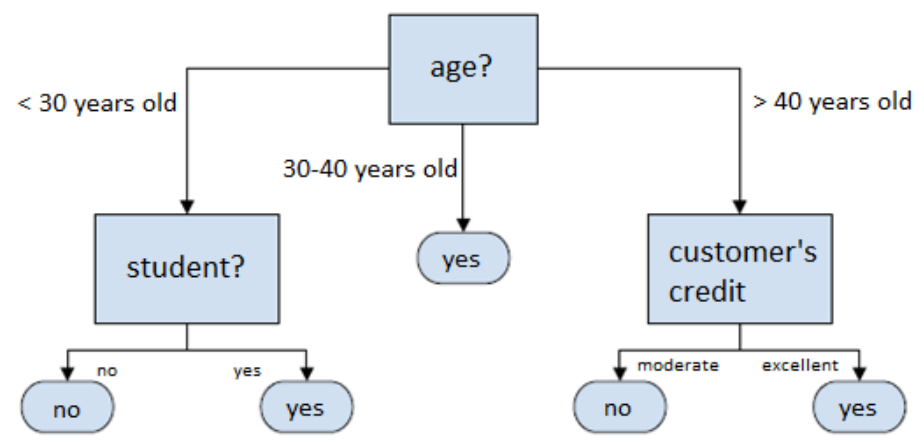

Figure 1 - An example of a decision tree

Decision tree is one of the powerful and common methods for classification and prediction. Unlike neural networks, the decision tree generates law, i.e., the prediction obtained by the decision tree structure is described by a set of rules, while only the results are predicted in the neural networks and the method of achieving those results remains unknown. Furthermore, unlike neural networks, it is not necessary for the data to be numerical in the decision tree. In some cases, only the correctness of classification and accuracy of prediction obtained by it is important, and there is no need to provide at explanation for the prediction made. Some characteristics of decision tree are:

- Not removing the data in classification into different groups

- Using decision tree techniques during marketing and seeking for new customers accepting our product offers is very useful.

- Ease of understanding the model presented. In other words, although understanding the working 
Ф.Х. Кашані, 3. Шахмірзалу. Розробка стратегій маркетингу з використанням управління взаємовідносинами 3 клієнтами та збору даних (приклад дослідження: сеть ресторанов Perperook)

procedure of algorithms creating the tree might not be easy, understanding the results obtained by them is.

- Classifications made by decision tree can be done based on similarity of the data stored in the predicting parameters.

Association rules. Association rules are one of the major techniques in data mining, and are almost the most form of discovering and extraction the patterns in a learning system. Association rules discover the attractive relationship between a great set of data. This relationship can help the decision-makers. In fact, the association rules represent conditions repeatedly happening in a data set at a same time. The rules extracted explain the presence of some features based on other features. Some basic concepts have to be defined before introducing the algorithms related to exploring the association rules:

- The set of items existing in a database is represented by ltem Set $=\{X 1, X 2, \ldots .$.$\} .$

- For any rule as $Y>X$, two values are specified: support and confidence.

- The probability of simultaneous presence of $X$ and $Y$ is combined in the transaction (support).

- There is a conditional probability for the transaction having $X$ to have $Y$ as well (confidence).

Therefore, the rule $Y>X$ with $S=50 \% \& C=7.66 \%$ means that $X$ and $Y$, combined together, are present in 50 percent of transactions, and in 7.66 percent of the transactions, $Y$ will be present whenever $\mathrm{X}$ is present. Exploring association rules in databases involves the two following stages:

- Discovering the largest item set (set of items with support value greater than a certain level).

- Using the item set discovered in previous step and creating association rules.

Generally, most tasks are done to optimize execution of the first step, i.e., discovering the largest item set since finding the rules directly would be possible by having the largest set of data. The following discusses different algorithms proposed to discover the largest item set.

Apriori algorithm. Apriori algorithm was used in this study to discover association rules. Using this algorithm has been recommended by many researchers due to its high responding speed. First, the minimum value of prior support and the minimum confidence was specified. Increasing these values results in fewer, but more credible rules. The input of this algorithm is a set taken from the set of rules. This algorithm tries to find subset of items shared at least between $\mathrm{C}$ sets of items. Apriori is a down-toup algorithm, so that an item is added to the repetitive subsets at each stage (generating candidate). The set of candidates are evaluated in the data. The end condition of the algorithm is lack of presence of another successful development method. The purpose of this algorithm is finding the largest item set meeting minimum support and confidence. The two following assumptions are considered in this algorithm:

- Any subset taken from a repetitive item set will be repetitive itself (i.e., if the set $\{a, b, c\}$ is assumed to be repetitive, the set $\{a, b\}$ will be repetitive as well).

- Any superset of a non-repetitive item set is non-repetitive itself (i.e., if $\{a, b\}$ is non-repetitive, the set $\{a, b, c\}$ will also be non-repetitive).

The Apriori algorithm works in a way that it generates an item set of length $(k+1)$ from the candidate item set of length $(K)$ at each repetition, and continues it until reaching an item set of maximum length. The key item set is obtained by multiplying the candidate set by it. The problems associated with this method are great volume of transactions in the database, their long-time search in each repetition, and large number of candidates in each repetition.

Analysis of research findings.

Descriptive study of research variables. Investigating the database under study, 3071 records were identified as the raw data. During data treatment process, 13 records were deleted due having over $50 \%$ blank fields, 45 records were deleted due to being repetitive, and 13 records were deleted due to having outlier data. Finally, 3000 records were analyzed as valid data. The statistical results obtained by research data are given in the following Table 2 and Table 3 in terms of continuous and discrete variables. 
Table 2 - Statistical results of continuous variables of the research

\begin{tabular}{|c|c|c|c|c|c|}
\hline No. & Feature & Description & Type & Minimum & Maximum \\
\hline 1 & ID & Customer's account number & Numerical & ---- & -- \\
\hline 2 & AGE & Customer's age & Numerical & 16 & 50 \\
\hline 3 & MONEY & The monetary volume purchased & Numerical & 100007 & 498666 \\
\hline
\end{tabular}

Table 3 - Statistical results of discrete variables of the research

\begin{tabular}{|c|c|c|c|c|c|}
\hline No. & Feature & Description & Type & \multicolumn{2}{|c|}{ Statistical distribution } \\
\hline 4 & SEX & Customer's sex & Binary & Male $(49 \%)$ & Female $(51 \%)$ \\
\hline 5 & PMETHOD & Payment method & Binary & Cash $(37 \%)$ & Credit card $(63 \%)$ \\
\hline 6 & HOMETOWN & Region & Binary & Inside the region $(49 \%)$ & Outside the region $(51 \%)$ \\
\hline
\end{tabular}

Besides descriptive study of the research variables, statistical distribution of the shopping cart items purchased by the customers was studied, whose results are given in the Table 4 .

Table 4 - Statistical results of discrete variables of the research

\begin{tabular}{|c|c|c|c|c|}
\hline No. & Item & Type & Yes & NO \\
\hline 1 & Season Salad & Binary & $30 \%$ & $70 \%$ \\
\hline 2 & Pizza 1 & Binary & $18 \%$ & $82 \%$ \\
\hline 3 & Pizza 2 & Binary & $18 \%$ & $82 \%$ \\
\hline 4 & Caesar Salad & Binary & $30 \%$ & $70 \%$ \\
\hline 5 & Hamburger & Binary & $20 \%$ & $80 \%$ \\
\hline 6 & Hotdog & Binary & $30 \%$ & $70 \%$ \\
\hline 7 & French Fries & Binary & $29 \%$ & $71 \%$ \\
\hline 8 & Fried Chicken Wings & Binary & $29 \%$ & $71 \%$ \\
\hline 9 & Soft Drink & Binary & $18 \%$ & $82 \%$ \\
\hline 10 & Vegetable Pizza & Binary & $29 \%$ & $71 \%$ \\
\hline 11 & Fried Shrimp & & & $72 \%$ \\
\hline
\end{tabular}

After normalizing, treating, and cleansing the data, the database was introduced to the software in Excel format, and shown in customer's shopping cart after performing the required adjustments for the sake of better understanding and easier interpretation on all samples using network graph of relationship between the items purchased (Figure 2).

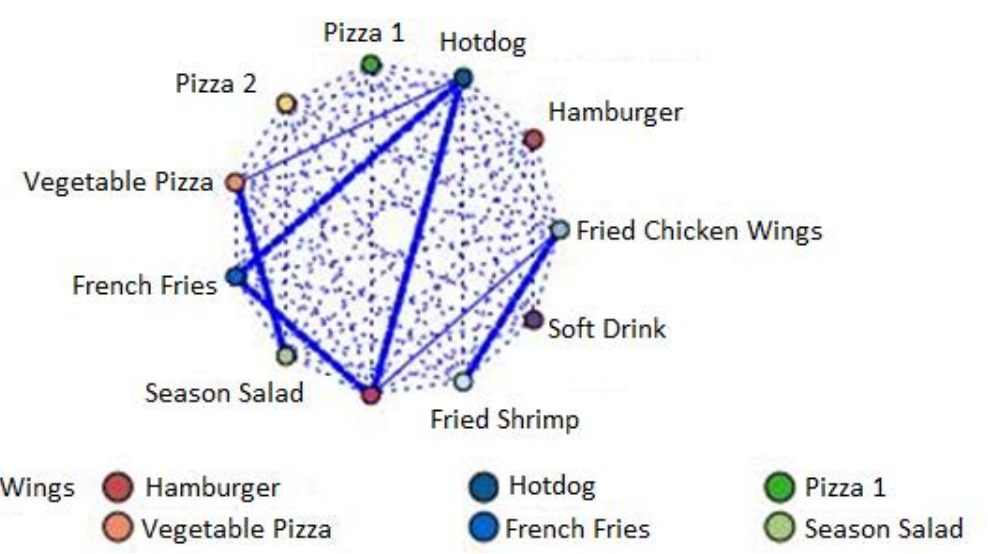

Figure 2 - Network graph of the relationship between the customers' shopping carts items 
Ф.Х. Кашані, 3. Шахмірзалу. Розробка стратегій маркетингу з використанням управління взаємовідносинами 3 клієнтами та збору даних (приклад дослідження: сеть ресторанов Perperook)

According to Table 5 , the following items have a high correlation with each other:

- Hotdog, French fries, Cesar salad

- Vegetable pizza, season salad

- Fried shrimp, fried chicken wings

Table 5 - Results of Apriori

\begin{tabular}{|c|c|c|c|c|}
\hline Result & Previous & Support & Confidence & Lift index \\
\hline French fries & Hotdog, Cesar salad & 17.3 & 84.393 & 2.88 \\
\hline Cesar salad & French fries, hotdog & 17 & 85.882 & 2.834 \\
\hline Hotdog & Cesar salad, French fries & 16.7 & 87.425 & 2.895 \\
\hline
\end{tabular}

Association rule and Apriori algorithm. One of the most important parts of data mining is discovering association rules in the database. These rules guarantee the necessity of presence of some features (items) in case of presence of other items. Item set: any subset taken from the set of items (I) is called an "item set". In most of the algorithms, discovering the continuity rules is divided into the two following sub-problems:

1. Finding all subsets of "l" (item set) whose frequency (occurrence) in the dataset is determined to be greater than one. The set of items whose frequency of occurrence is equal to, or greater than, the specified level are called "large item set", and others are called "small item set".

2. Using large item sets to generate the desired rules.

An Apriori algorithm was used to discover association rules. The working procedure is so that the algorithm used a set of $K$ elements to find an item set with $(K+1)$ elements. The steps involved in this algorithm are:

- Set K=1.

- Generate a set of repeated objects with length of 1.

- Continue the following steps until no repeated item set is generated:

- Obtain the candidate set of objects with length of $(\mathrm{K}+1)$ from the repeated set of objects with length of $(\mathrm{K})$.

- Remove the set of candidate objects having a non-repetitive subset of length (K).

- Obtain the support value of each candidate by searching in the transaction database.

- Remove non-repetitive candidates, and keep only the repetitive ones.

The minimum support and confidence considered in this study were $10 \%$ and $80 \%$, respectively. Thereupon, the following rule was extracted from the database:

The lift index was used to evaluate association rules. This index is obtained by dividing confidence over support value. The greater the value than 1 , the more attractive the rule extracted. According to the network graph of relationship between the products, 3 classes of customers were identified, whose shopping behavior and shopping cart is as the following (Table 6):

Table 6 - Labeling the customers based on shopping cart analysis

\begin{tabular}{|c|c|c|}
\hline No. & Class of customers & Description of the products purchased \\
\hline 1 & Customers caring for health & Vegetable pizza, season salad \\
\hline 2 & Customers caring for food volume & Hotdog, French fries, Cesar salad \\
\hline 3 & Free-living customers & Fried shrimp, fried chicken wing \\
\hline
\end{tabular}

According to the product groups extracted, the decision tree is used in the following to discover the rules associated with the products purchased and people's demographic features. 
C5 decision tree. This model is used to generate a decision tree or a set of principles. This model can generate more than two sub-nodes for some nodes as required, and its target field must be stratified (Figure 3 and Figure 4).

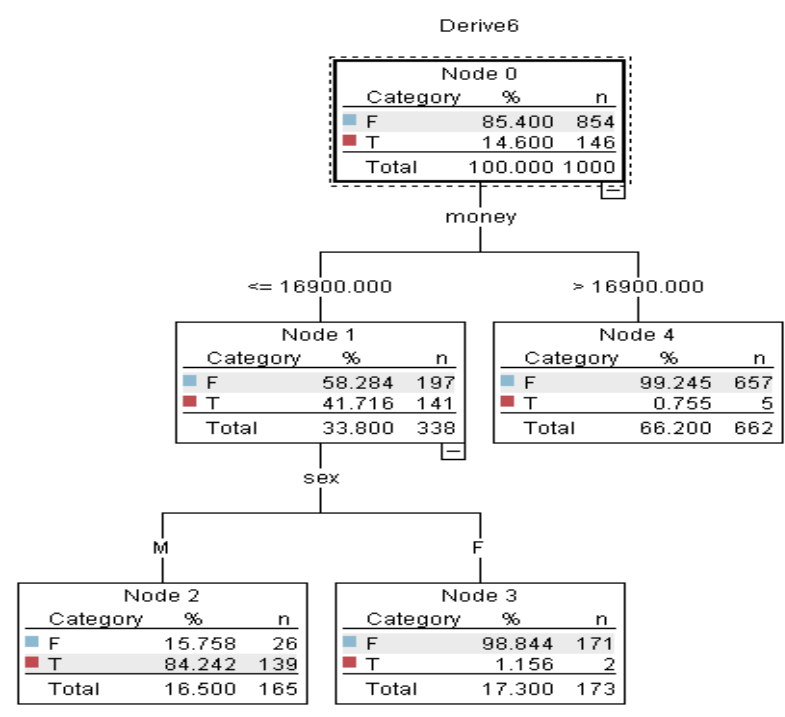

Figure $3-\mathrm{C} 5$ decision tree

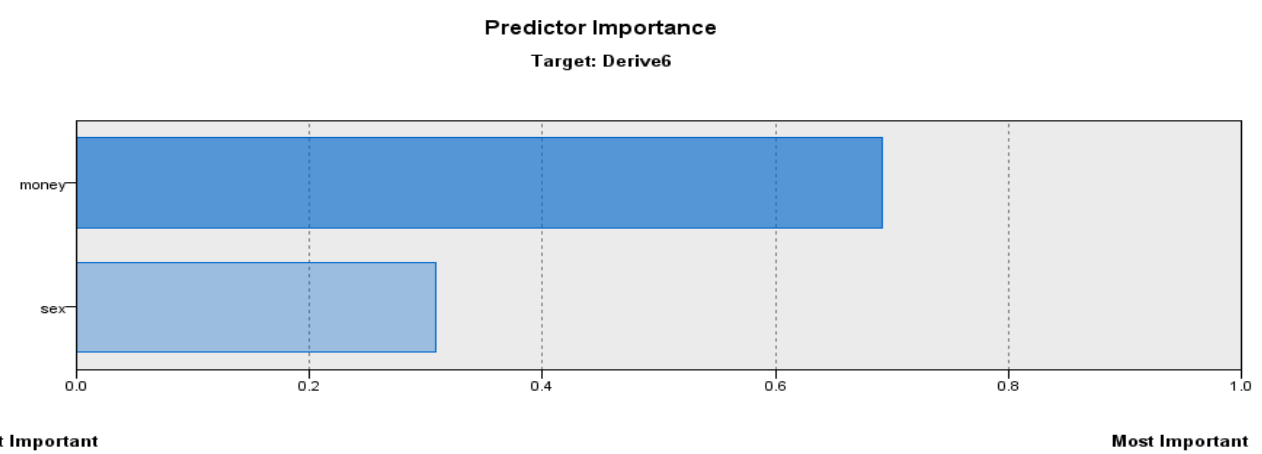

Figure 4 - Important and influential variables in labeling the customers based on C5 decision tree

The monetary volume of purchase and sex are two influential variables in labeling the customers based on this decision tree. According to the nodes obtained, the rules of this tree are:

- If the sex is male and the monetary volume is less than 169,000 IRR, the customers will fit one of the three classes identified.

- If the sex is female and the monetary volume is greater than 169,000 IRR, the customers won't fit any of the three classes identified.

According to the results obtained by this decision tree, the model accuracy for educational and test data is $97 \%$ and $96 \%$, respectively (Figure 5 and Figure 6). 
Ф.Х. Кашані, 3. Шахмірзалу. Розробка стратегій маркетингу з використанням управління взаємовідносинами 3 клієнтами та збору даних (приклад дослідження: сеть ресторанов Perperook)

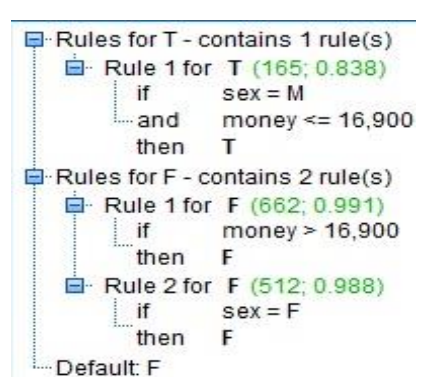

Figure 5 - The rules extracted from $\mathrm{C} 5$ decision tree

曰-Results for output field Derive6

由. Comparing \$C-Derive6 with Derive6

\begin{tabular}{|l|r|r|r|r|}
\hline 'Partition' & 1_Training & 2_Testing & \\
\hline Correct & 1930 & $96.75 \%$ & 965 & $96.52 \%$ \\
\hline Wrong & 70 & $3.25 \%$ & 35 & $3.48 \%$ \\
\hline Total & 2000 & & 1000 & \\
\hline
\end{tabular}

Figure 6-Accuracy of C5 decision tree

Quest decision tree. Quest is a single-variable binary tree, which uses standard linear separation. This tree is upgraded version of the FACT tree. It uses Kido-Pearson test to calculate the relationship between any of the input features and the target. The F-test, which is the generalized version of t-test, is used in this method to evaluate the similarity and difference between two or more population. In this test, the total population variance test is broken down to its primary factors. Therefore, it is also called variance analysis test. This test is sued when it is decided to compare the correlation between a number of populations, rather than two populations since comparing the mean values of a number of populations is very difficult by t-test. This test is used to investigate the equality of variance between two populations. Given the outputs of this tree, the important parameters in labeling the customers are money and sex (Figure 7, Figure 8 and Figure 9).

Predictor Importance

Target: Derive6

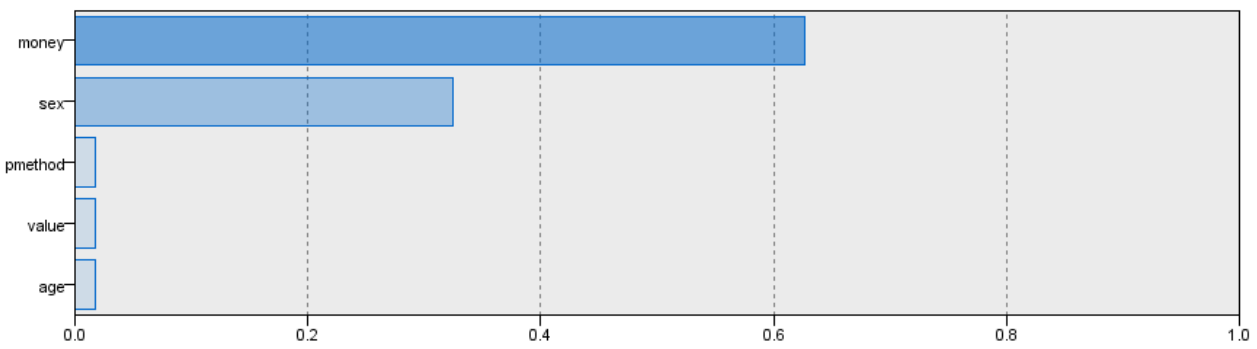

Least Important

Most Important

Figure 7 - Important and influential variables in labeling the customers based on Quest decision tree 


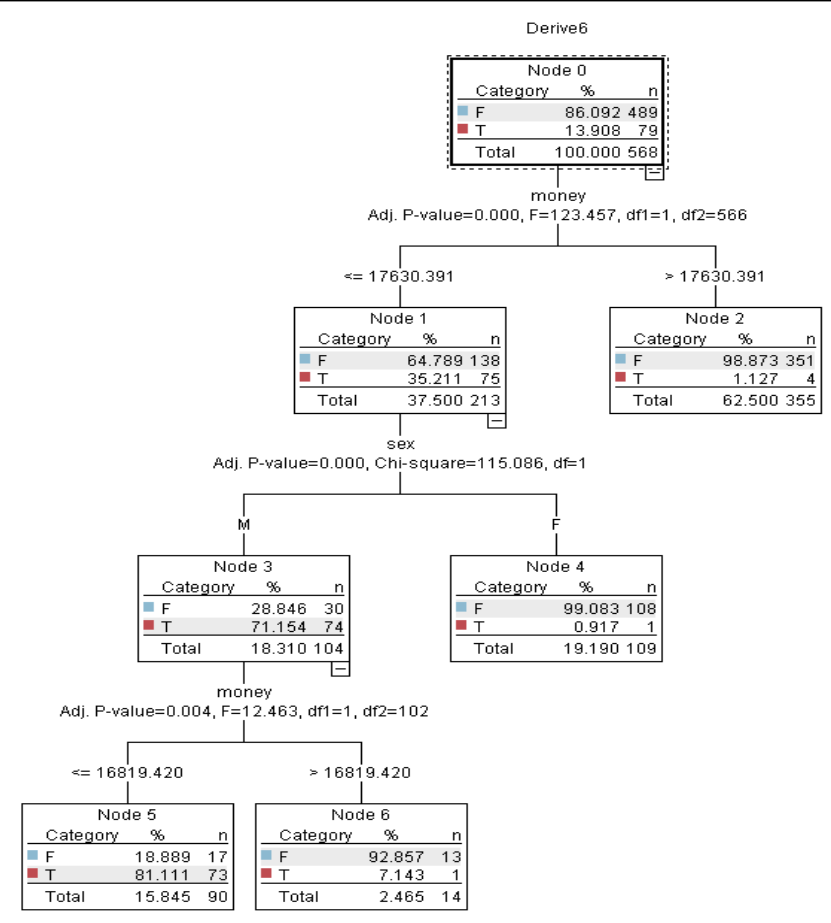

Figure 8-Quest decision tree

घ. Results for output field Derive6
由. Comparing \$R-Derive6 with Derive 6
\begin{tabular}{|l|r|r|r|r|}
\hline 'Partition' & 1_Training & 2_Testing & \\
\hline Correct & 1925 & $96.62 \%$ & 965 & $96.52 \%$ \\
\hline Wrong & 75 & $3.38 \%$ & 35 & $3.48 \%$ \\
\hline Total & 2000 & & 1000 & \\
\hline
\end{tabular}

Figure 9 - Accuracy of Quest decision tree

According to the results obtained by this decision tree, the accuracy of this model for educational and test data is $97 \%$ and $96 \%$, respectively.

Conclusion and recommendation. The purpose of this study was to analyze customers' shopping cart and propose a model to improve Customer Relationship Management process in Perperook fast food. The findings of this research showed that customer classification can help identify their hidden pattern in purchasing behavior, which can be used for improving the decisions in Perperook chain restaurants. The ultimate goal of this research was to extract easy rules for decision making in the context of developing CRM strategies. According to Pareto Principle, 80 percent of an organization's profit is obtained from 20 percent of its customers. Therefore, the organizations must identify the customers' importance level, and recognize which customers have a higher share in organization's profit. This study used Apriori algorithm to identify the products purchased in customers' shopping cart in order to answer its first question, i.e., analyzing customers' shopping cart using data mining algorithm. The rules and principles hidden in customers' profile were also extracted using decision tree algorithms. 
Ф.Х. Кашані, 3. Шахмірзалу. Розробка стратегій маркетингу з використанням управління взаємовідносинами 3 клієнтами та збору даних (приклад дослідження: сеть ресторанов Perperook)

Moreover, regarding the objectives of this study, one can discuss developing marketing strategies after identifying the target customers in order to promote efficient relationship with customer. Therefore, the Table 7 is designed to answer both questions mentioned earlier, so that it could be the basis of developing marketing strategies for Perperook chain restaurants.

\section{Table 7 - Customer classification based on the rules extracted and development of marketing strategies specific to each class}

\begin{tabular}{|c|c|c|}
\hline $\begin{array}{c}\text { Type of } \\
\text { customer }\end{array}$ & $\begin{array}{c}\text { Food } \\
\text { purchased }\end{array}$ & Marketing strategies \\
\hline Healthy & $\begin{array}{l}\text { Vegetable } \\
\text { pizza, } \\
\text { season salad }\end{array}$ & $\begin{array}{l}\text { - Using advertising slogans focused on healthy food for fans of these products } \\
\text { - Attending advertising campaigns focused on supporting healthy food } \\
\text { - Active presence in social networks focused on preserving the environment } \\
\text { - Distributing advertising teasers of the process of producing these products without using oil } \\
\text { - Mentioning the contents of these products in leaflets used by the customers }\end{array}$ \\
\hline Voluminous & $\begin{array}{l}\text { Hotdog, } \\
\text { French fries, } \\
\text { Cesar salad }\end{array}$ & $\begin{array}{l}\text { - Considering promotional initiatives, e.g., a free starter to increase sales of hotdog } \\
\text { - Redesign and redevelopment of hotdog products (e.g., using larger bread, increasing the } \\
\text { sandwich contents, etc.) } \\
\text { - Offering various sauces to the customers along with serving hotdog } \\
\text { - Offering considerable discounts in case of ordering this product at night } \\
\text { - Offering discount to customers serving this product in the salon }\end{array}$ \\
\hline Free-living & $\begin{array}{l}\text { Fried shrimp, } \\
\text { fried chicken } \\
\text { wings }\end{array}$ & $\begin{array}{l}\text { - Addressing the adolescents and young adults to serve these products } \\
\text { - Publishing advertising tools, namely brochure and leaflet, with pictures of these products in } \\
\text { order to attract the audience and stimulate their appetite } \\
\text { - Opening branches in crowded areas due to presence of audiences }\end{array}$ \\
\hline
\end{tabular}

The research results indicated that using Apriori algorithm for the available data, three classes of customers were identified: caring for health, caring for food volume, and free living. Table 7 shows customer classification and the food purchased by them. Moreover, using C5 decision tree indicated that variables such as the monetary volume purchased and sex are the factors influencing the type of food purchased by the customer. Compared to the literature, the findings of this research are also interesting. Hosseinzadeh-Shahri et al.[3] addressed classification and analyzing the shopping cart of Boof fast food customers across Tehran City. They showed that there are three classes of customers in this fast food: interested in health, easygoing, and indifferent. In their studies performed in American fast foods, Jang et al.[22] identified four groups of customers: aware of health, indifferent, easygoing, and adventurous. Kim at al.[5] addressed identifying fast food customers and labeling them based on sensitivity to food health, volume, and price. According to the results obtained in this study, the following suggestions are made tailored to the customers identified:

- Categorizing the products, focusing on healthy food in the advertising tools such as leaflet, billboard, etc.

- Positioning the branches of this fast food around recreation and sports centers, where there is a higher possibility for presence of the youth.

- Offering the main course along with different sides, including French fries and cola, and giving promotions in this class.

- Offering larger sandwiches or offering foods with extra bread in order to make sure the customers are full.

- Training the cashiers for introducing the set of foods to the customers and increasing their knowledge regarding the foods served in this fast food.

According to the rules and principles extracted in customers' profile, the following suggestions are also made: 
- Given the important role of money and sex as two variables, it is suggested that the advertising schemes be implemented specific to these variables, and their result be evaluated.

- In order to retain the loyal customers, it is suggested to use advertising campaigns tailored to daily community events.

- In order to increase the customers attending the branches, more activity in the social networks and attracting the customers is suggested.

- It is also suggested to design a professional system based in the rules extracted from the decision tree to be aware of the customer's shopping behavior and their loyalty status.

- It is suggested to grant a credit card to the customers from the organization to record their loyalty status in the systems such as customers club.

- Other variables, such as the monetary purchase volume, purchasing frequency, and last purchase date, can also be used for labeling the customers.

- It is suggested to distribute questionnaires periodically in the branches to become aware of customers preferences.

Suggestions for future studies.

- Using other statistical populations, e.g., other chain fast foods, to cluster the customers and compare the results with the results of current study.

- Using other data mining methods and algorithms, such as neural networks and Bayesian networks, to identify the important research variables.

- Think tank sessions can be used to find customers preferences, and investigate the loyalty status of the customers by this method (face to face interview).

1. Berson, A., \& Smith, S.J. (2002). Building data mining applications for CRM. McGraw-Hill.

2. Cheng, C.H., \& Chen, Y.S. (2009). Classifying the segmentation of customer value via RFM model and RS theory. Expert systems with applications, 36, 4176-4184.

3. Hosseinzadeh-Shahri, M., Karami, M., \& Merabani, M. (2015). Customer classification in chain restaurants based on food style (Case study: Boof fast food restaurants in Tehran City). Tehran University publication.

4. Ngai, E.W., Xiu, L., \& Chau, D.C. (2009). Application of data mining techniques in customer relationship management: A literature review and classification. Expert systems with applications, 36, 2592-2602.

5. Kim, M.J., Jung, H.S., \& Yoon, H.H. (2007). A study on the relationships between food-related lifestyle of undergraduates and the restaurant selection attribute. Journal of the Korean Society of Food Culture, 22(2), 210-217.

6. Ghazanfari, M., Alizadeh, S., \& Teimourpour, B. (2008). Data mining and knowledge discovery. Elm-o-Sanat University Press, Tehran, 1st Ed.

7. Han, J., \& Kamber, M. (2006). Data Mining: Concepts and Techniques, 2nd edition. Morgan Kaufmann Publishers. San Francisco, CA, USA.

8. Funatsu, K., \& Hasegawa, K. (2011). New fundamental technologies in data mining. First published January, Printed in India.

9. Pang-Ning, T., Steinbach, M., \& Kumar, V. (2006). Introduction to data mining. In Library of congress.

10. Liang, Y.H. (2010). Integration of data mining technologies to analyze customer value for the automotive maintenance industry. Expert systems with Applications, 37, 7489-7496.

11. Liao, S.H., Chen, C.M., \& Wu, C.H. (2008). Mining customer knowledge for product line and brand extension in retailing. Expert Systems with Applications, 34, 1763-1776.

12. Kracklauer, A.H., Mills, D.Q., \& Seifert, D. (2004). Collaborative customer relationship management: taking CRM to the next level. Springer Science \& Business Media.

13. Chang, H. C., \& Tsai, H.P. (2011). Group RFM analysis as a novel framework to discover better customer consumption behavior. Expert Systems with Applications, 38, 14499-14513.

14. Fan, B., \& Zhang, P. (2009). Spatially enabled customer segmentation using a data classification method with uncertain predicates. Decision Support Systems, 47, 343-353.

15. Khajvand, M., Zolfaghar, K., Ashoori, S., \& Alizadeh, S. (2011). Estimating customer lifetime value based on RFM analysis of customer purchase behavior: Case study. Procedia Computer Science, 3, 57-63.

16. Shahrabi, J., \& Soofi-Neyestani, R. (2008). Analyzing customers' shopping cart using association rules in Shahrvand chain stores. 2nd Iranian Conference on Data Mining, Amir Kabir University of Technology pubication, Tehran.

17. Liao, S.H., Chu, P.H., \& Hsiao, P.Y. (2012). Data mining techniques and applications-A decade review from 2000 to 2011. Expert Systems with Applications, 39, 11303-11311. 
Ф.Х. Кашані, 3. Шахмірзалу. Розробка стратегій маркетингу з використанням управління взаємовідносинами 3 клієнтами та збору даних (приклад дослідження: сеть ресторанов Perperook)

18. Hsieh, N.C. (2004). An integrated data mining and behavioral scoring model for analyzing bank customers. Expert systems with applications, 27, 623-633.

19. Kim, S.Y., Jung, T.S., Suh, E.H., \& Hwang, H.S. (2006). Customer segmentation and strategy development based on customer lifetime value: A case study. Expert systems with applications, 31, 101-107.

20. Wei, J.T., Lee, M.C., Chen, H.K., \& Wu, H.H. (2013). Customer relationship management in the hairdressing industry: an application of data mining techniques', Expert Systems with Applications, 40, 7513-7518.

21. Bahari, T.F., \& Elayidom, M.S. (2015). An Efficient CRM-Data Mining Framework for the Prediction of Customer Behaviour. Procedia Computer Science, 46, 725-731.

22. Jang, Y.J., Kim, W.G., \& Bonn, M.A. (2011). Generation Y consumers' selection attributes and behavioral intentions concerning green restaurants. International Journal of Hospitality Management, 30, 803-811.

Ф.X. Кашані, асистент, факультет менеджменту, Центральний Тегеранський філія, Ісламський університет Азад (м. Тегеран, Іран);

3. Шахмірзалу, магістр, факультет менеджменту, Центральний Тегеранський філія, Ісламський університет Азад (м. Тегеран, Іран)

Розробка стратегій маркетингу з використанням управління взаємовідносинами 3 клієнтами та збору даних (приклад дослідження: мережа ресторанів Perperook)

Поряд з підвищенням конкурентоспроможності в сфері послуг для збільшення числа клієнтів $і$ отримання конкурентних переваг шляхом створення задоволеності клієнтів використання концепцій інтелектуального аналізу привернуло увагу дослідників і галузей як новий інструмент для цієї мети. У зв'язку з иим, індустрія швидкого харчування, як галузь, яка все більше зростає в останні роки, вважається дуже привабливим ринком для клієнтів. У даний час дослідження спрямоване на використання алгоритмів інтелектуального аналізу даних для категоризації клієнтів в харчовій промисловості і пропонує маркетингові стратегії, адаптовані до кожної групи ідентисрікованих клієнтів. Статистичне населення иього дослідження включає дані, представлені в інтегрованій системі ресторанів мережі Perperook, яка складає більше 3000 документів. Крім того, алгоритми інтелектуального аналізу даних, зокрема дерево рішень і алгоритм Quest, були використані в цьому дослідженні для категоризації клієнтів відповідно до замовлень, представленими в системі. Результати иього дослідження показують, що клієнтів ресторану швидкого харчування Perperrok можна розділити на три основні групи: здорові, основна більшість і клієнти, які вільно живуть. У кінці дослідження представлені детальні результати і стратегії, пов'язані з будь-якою з основних груп клієнтів, а також практичні пропозиції.

Ключові слова: управління взаємовідносинами з клієнтами, інтелектуальний аналіз даних, алгоритм Apriori, дерево рішень.

Ф.X. Кашани, ассистент, факультет менеджмента, Центральный Тегеранский филиал, Исламский университет Азад (г. Тегеран, Иран);

3. Шахмирзалу, магистр, факультет менеджмента, Центральный Тегеранский филиал, Исламский университет Азад (г. Тегеран, Иран)

Разработка стратегий маркетинга с использованием управления взаимоотношениями с клиентами и сбора данных (пример исследования: сеть ресторанов Perperook)

Наряду с повышением конкурентоспособности в ссфере услуг для увеличения числа клиентов и получения конкурентных преимуществ путем создания удовлетворенности клиентов использование концепций интеллектуального анализа привлекло внимание исследователей и отраслей как новый инструмент для этой цели. В связи с этим, индустрия быстрого питания, как отрасль, которая все больше растет в последние годы, считается очень привлекательным рынком для клиентов. В настоящее время исследование направлено на использование алгоритмов интеллектуального анализа данных для категоризации клиентов в пищевой промышиенности и предлагает маркетинговые стратегии, адаптированные к каждой группе идентифицированных клиентов. Статистическое население этого исследования включает данные, представленные в интегрированной системе ресторанов сети Perperook, которая составляет более 3000 документов. Кроме того, алгоритмы интеллектуального анализа данных, 6 частности дерево решений и алгоритм Quest, были использованы в этом исследовании для категоризации клиентов в соответствии с заказами, представленными в системе. Результаты этого исследования показывают, что клиентов ресторана быстрого питания Perperrok можно разделить на три основные группь: здоровые, основное большинство и свободноживущие клиенты. В конце исследования представлены подробные результаты и стратегии, связанные с любой из основных групп клиентов, а также практические предложения.

Ключевые слова: управление взаимоотношениями с клиентами, интеллектуальный анализ данных, алгоритм Apriori, дерево решений.

Отримано 09.01.2017 p. 